YEARBOOK
of ANTITRUST
and REGULATORY
STUDIES
www.yars.wz.uw.edu.pl

Peer-reviewed scientific periodical, focusing on legal and economic issues of antitrust and regulation. Creative Commons Attribution-No Derivative Works 3.0 Poland License.

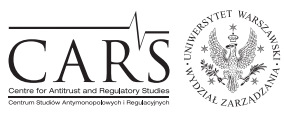

Centre for Antitrust and Regulatory Studies, University of Warsaw, Faculty of Management www.cars.wZ.uw.edu.pl

\title{
Liability for Anti-Competitive Conduct of a Third Party under EU Competition Law
}

\author{
by \\ Magdalena Knapp*
}

\section{CONTENTS}

I. Introduction

II. Concepts of third party liability in the light of the principle of personal responsibility

III. Genuinely independent third party

IV. Test for the attribution of anti-competitive conduct of a service provider

V. Grounds for exemption from liability for actions of a genuinely independent contractor

VI. Issues left unresolved

VII. Conclusion

\section{Abstract}

The article discusses the framework of liability for anti-competitive conduct of a genuinely independent third party as set forth in relevant judgments. It refers to concepts of third party liability in the light of the principle of personal responsibility developed by doctrine and jurisprudence. The CJEU has set out important rules relating to liability of an undertaking for actions of its independent service provider. However, it still left some important issues unresolved. The paper focuses on the test for the attribution of anti-competitive conduct of a service provider and refers to its interpretation and application. It questions whether the introduced test provides sufficient legal certainty for undertakings. It briefs on the steps that must

* PhD candidate at the Department of Public Economic Law at the University of Białystok, e-mail: knapp.magdalena@gmail.com. An earlier version of this contribution was presented at the First Gaetano Filangieri Conference on Freedom of Commerce 'Recent developments in EU Competition Law', held at the University of Naples 'Federico II' on 8-9 May 2018. Article received: 12 April 2018, accepted: 6 June 2018. 
be taken by undertakings to distance themselves from an infringement and offers some suggestions how to limit or prevent exposure to liability.

\section{Résumé}

Larticle traite du cadre de la responsabilité d'un tiers véritablement indépendante pour un comportement anticoncurrentiel, tel qu'énoncé dans les jugements pertinents. Il fait référence aux concepts de responsabilité d'un tiers à la lumière du principe de la responsabilité personnelle développé par la doctrine et la jurisprudence. La CJUE a énoncé des règles importantes relatives à la responsabilité d'une entreprise pour les actions de son prestataire de services indépendant. Cependant, certaines questions importantes n'ont toujours pas été résolues. Larticle se focalise sur le test d'attribution du comportement anticoncurrentiel d'un prestataire de services et se réfère à son interprétation et à son application. Il s'interroge sur le point de savoir si le test introduit offre une sécurité juridique suffisante aux entreprises. Il fait un résumé des mesures à prendre par les entreprises pour se distancer par rapport à une infraction et propose des suggestions sur la manière de limiter ou d'empêcher toute exposition à la responsabilité.

Key words: third party, independent service provider, attributed liability, personal liability

JEL: K10, K21, K41.

\section{Introduction}

Recent judgments of the CJEU provide valuable insight into the circumstances where an undertaking is liable for actions of a third party. Liability for an unlawful conduct of an independent contractor is a quite recent competition law concept. It is consistent with the trend of extending the scope of Article 101 TFEU that is to include new forms of cartels and its participants as well as to ensure the effectiveness of the prohibition laid down in this article. The paper refers to situations when a company is held liable for a cartel established by its service provider without having to establish a personal involvement of the former in the infringement. The issue of an undertaking's liability for actions of a genuinely independent third party is not codified. Consequently, there are no universal or standard rules, just the general framework of the liability regime. The article aims to synthesize relevant case law and provide rules which would allow undertakings to understand whether they are liable for actions of companies they are contracting. 
In order to avoid terminological confusion, in this paper, 'third party' is defined as a business partner or contractor that provides services to the undertaking in question. To speak about a truly independent contractor it has to: 1) have a separate legal personality 2) bear relevant financial and economic risks and 3) act in its own name. The term third party is often used interchangeably with the notions of 'contractor', 'service provider', 'agent', and 'economic operator'.

EU authorities stress the need to eliminate situations when an undertaking outsources services in order to free itself from suspicion of participating in concerted practices or anti-competitive agreements. Authorities want to attribute liability directly to an undertaking that has outsourced its activities. Accordingly, the CJEU expressed an opinion that an undertaking may be held accountable not only for its own actions, or actions of its employees, but also for the actions of independent contractors entrusted with specific tasks. The Court contributes to a wider interpretation of the prohibition laid down in Article 101 TFEU in order to 'penalize and to prevent the creation of new forms of collusion with the assistance of undertakings which are not active on the markets concerned by the restriction of competition'. ${ }^{1}$ In the Court's view, such interpretation will prevent situations aimed at circumventing it. That reasoning is also applicable to service providers.

A key role of competition authorities is to ensure that competition rules are effectively enforced. Once an infringement is found, an authority 'must provide sufficiently precise and consistent evidence to support the firm conviction that the alleged infringement took place'. ${ }^{2}$ The possibilities offered by modern technology and the character of some cartels and concerted practices has

\footnotetext{
1 This approach was presented by the Court of First Instance in para. 127 of judgment of 08.07.2008, Case T-99/04 Treuhand v Commission, ECLI:EU:T:2008:256.

2 Para. 56 of judgment of 24.03.2011, Case T-377/06 Comap SA, ECLI:EU:T:2011:108. Standard of proof is further explained in paras 63 and 64 of the judgment of 13.07.2011,Case T-53/07 Trade-Stomil sp. $z$ o.o., ECLI:EU:T:2011:360 'As regards proof of an infringement of Article [101 TFEU], the Commission must prove the infringements which it has found and adduce evidence capable of demonstrating to the requisite legal standard the existence of circumstances constituting an infringement. It is accordingly necessary for the Commission to produce precise and consistent evidence to support the firm conviction that the infringement took place (...) Furthermore, it is normal for the activities entailed by anti-competitive practices and agreements to take place clandestinely, for meetings to be held in secret and for the associated documentation to be reduced to a minimum. It follows that, even if the Commission discovers evidence explicitly showing unlawful contact between traders, it will normally be only fragmentary and sparse, so that it is often necessary to reconstitute certain details by deduction. Accordingly, in most cases, the existence of an anti-competitive practice or agreement must be inferred from a number of coincidences and indicia which, taken together, may, in the absence of another plausible explanation, constitute evidence of an infringement of the competition rules'.
} 
proven that it is an extremely difficult task to provide all incriminating evidence of an alleged infringement. Consequently, the CJEU introduced some presumptions to facilitate the work of the authorities. The emergence of those presumptions provides guidance for competition authorities on how to assess the limits of liability for anti-competitive conduct of a third party. That would include situations when an independent service provider facilitates collusion or is actually working on behalf of the undertaking in question, or when a number of undertakings use the same service providers to collude and exchange sensitive information to escape the radar of competition authorities. This would also ensure full effectiveness of the prohibition laid down in Article 101 TFEU as the Court stated in AC-Treuhand. ${ }^{3}$

The paper first reviews the concepts of an undertaking's responsibility for third party actions, referring to the principle of personal liability in competition law. Then it analyzes the circumstances when a third party is considered truly independent. Further, it refers to the framework of liability for anti-competitive conduct of a truly independent third party set forth in relevant judgments. It discusses practical implications for companies that rely on contractors and how an undertaking can distance itself from the infringement. Finally, it looks at issues that are still unresolved and call for clarification. As this article is concerned specifically with the scope of liability for anti-competitive conduct of a third party, the paper shall strive to answer the following questions:

- When is a service provider considered to be genuinely independent?

- Under what conditions may the conduct of a service provider be attributed to the undertaking in question and expose it to liability?

- How should an undertaking act to distance itself from the competition law infringement?

\section{Concepts of third party liability in the light of the principle of personal responsibility}

There are various cases where it seems that an undertaking is responsible for third party actions. In fact, these are the situations of personal liability where an economic entity, which may consist of several legal persons, answers for an infringement. If employees, subsidiaries or contractors are considered part of the undertaking, liability for their actions is attributed to that undertaking. Discussing the issue of liability for anti-competitive conduct of a third party requires reference to those concepts.

\footnotetext{
3 Para. 36 of judgment of 22.10.2015,Case C-194/14 P AC-Treuhand, ECLI:EU:C:2015:717.
} 
The first issue that will be analyzed is a violation of competition law committed by an employee. The relationship between an undertaking and a service provider may resemble that of an employer and employee with all its consequences. Well-established case law confirms that liability for an employee's anti-competitive behavior is attributed to the employer (undertaking). It is recognized that an employee is considered part of the organizational structure of an undertaking, because he performs his duties in accordance with the requirements of the employer. ${ }^{4}$ He bears no economic risk and he does not act on his own behalf. The concept dates back to $1983^{5}$ and continues to be used in recent judgments. ${ }^{6}$

The principle set out in 1983 in Musique Diffusion française states that 'to impose on undertakings or associations of undertakings fines where, intentionally or negligently, they have been guilty of infringements, is not conditional upon action by, or even knowledge on the part of, the partners or principal managers of the undertaking concerned but upon action by a person who is authorized to act on behalf of the undertaking'. Hence, there is no need for an action on the part of the employer in order to attribute liability for an employee's infringement to the undertaking in question, mere authorization to act on its behalf suffices. The following example illustrates the principle: if an employee exchanged confidential information with a competitor of his employer, the latter may be punished for the violations, even if it did not know that such an exchange took place. An undertaking is liable for actions of its rogue employees.

The employee performs duties under the direction of the undertaking with which he concluded an employment agreement. In this sense, the employee is integrated into the structure of the economic entity - that is, an undertaking. Therefore, any illegal conduct of an employee results in the undertaking being responsible for the violations committed by the employee, regardless of the fact whether the undertaking knew or was not aware of the anti-competitive conduct of its employee. Some guidance on how to prevent and limit employer liability is provided in paragraph 27 of Slovenská sporitelña: ${ }^{7}$ it is settled

\footnotetext{
${ }^{4}$ Para. 26 in judgment of 16.09.1999, Case C-22/98 Becu and Others, ECLI:EU:C:1999:419.

5 Judgment of 07.06.1983, Joined cases 100 to 103/80 Musique Diffusion française and Others v Commission, ECLI:EU:C:1983:158.

${ }^{6}$ The case law which confirm the validity of this concept includes: judgment of 21.07.2016, Case C-542/14 VM Remonts, ECLI:EU:C:2016:578, para. 23-27; judgment of 14.03.2013, Case T-588/08 Dole Food Company, ECLI:EU:T:2013:130, para. 581; judgment of 16.06.2015, Case T-655/11 FSL Holdings, ECLI:EU:T:2015:383, para. 303-304; judgment of 15.07.2015, Cases T-389/10 and T-419/10 Siderurgica Latina Martin SpA, ECLI:EU:T:2015:513, para. 405-412.

7 Judgment of 07.02.2013, Case C-68/12 Slovenská sporitelňa, ECLI:EU:C:2013:71. The case states that a service provider is not independent if in practice it is acting as an agent or employee.
} 
case-law that when it is established that an undertaking has participated in anti-competitive meetings between competing undertakings, it is for that undertaking to put forward evidence to establish that its participation in those meeting was without any anti-competitive intention by demonstrating that it had indicated to its competitors that it was participating in those meetings in a spirit that was different from theirs. If an undertaking's participation in such a meeting is not to be regarded as tacit approval of an unlawful initiative or as subscribing to what is decided there, the undertaking must publicly distance itself from that initiative in such a way that the other participants will think that it is putting an end to its participation, or it must report the initiative to the administrative authorities'.

In many EU jurisdictions, parent companies are liable for antitrust violations committed by their subsidiaries. There is a presumption that if a subsidiary is $100 \%$ owned by its parent company, than it is not independent and does not form a separate entity for the purpose of incurring liability. In such case, being the sole parent company is sufficient to attribute liability because the parent influences and controls its subsidiary. Even though a subsidiary has a separate legal personality, it does not have power to make autonomous decisions. For that reason, an agreement of an anti-competitive nature concluded between a parent and a subsidiary will not raise antitrust concerns, because they are not separate entities. According to the doctrine of a single economic entity, a parent company and a subsidiary are treated as one entity for the purpose of antitrust proceedings (Moisejevas and Urbonas, 2016, p. 109-111). Anticompetitive agreements concluded within a single economic unit are not unlawful due to their nature because: the entities are not independent, they do not have market autonomy and they are not perceived as competitors. Therefore, an agreement concluded between them cannot be defined as anticompetitive (Semeniuk, 2015, p. 34). For these reasons, subsidiaries are not truly independent third parties. Their actions are considered to be the actions of the undertaking in question (parent).

It is important to note in this context that a parent company which did not participate in the cartel directly is liable for it within the limits of the infringement committed by its subsidiary - in other words, the parent's liability cannot be more severe than that of its subsidiary. The Total $S A^{8}$ case confirms this in paragraph 44 stating that in a situation where the liability of a parent company is purely derivative of that of its subsidiary and in which no other factor individually reflects the conduct for which the parent company is held liable, the liability of that parent company cannot exceed that of its subsidiary'. Moreover, it must also be recalled that there is no need for

8 Para. 44 of judgment of 19.01.2017, C-351/15 P European Commission v Total SA and Elf Aquitaine SA, ECLI:EU:C:2017:27. 
a formal authorization to attribute liability to the undertaking in question if it is exercising decisive influence over the third party. If an employee or subsidiary is a formal representative of an undertaking, they can be considered part of that undertaking. In such case, it is irrelevant whether they were formally appointed. ${ }^{9}$

The Voestalpine ${ }^{10}$ judgment further explained when an undertaking and an independent contractor are treated as a single economic unit. In this case, a producer of metal products outsourced its sales to an agent on the territory of Italy, where cartel meetings were held. The agent was not authorized to sign contracts with customers, they were always concluded directly with the producer. ${ }^{11}$ It is important to note that the same agent worked also for another member of the cartel.

The court pointed out two factors that determine whether 'two companies having a vertical relationship, such as a principal and its agent or intermediary [form] single economic unit: first, whether the intermediary takes on any economic risk and, second, whether the services provided by the intermediary are exclusive'. ${ }^{12}$ Also 'it is necessary to ascertain whether that agent is in a position, as regards the activities entrusted to him by that principal, to act as an independent trader free to determine his own business strategy. If the agent is not in a position to act in that way, the functions which he carries out on behalf of the principal form an integral part of the latter's activities' ${ }^{13}$ In the presented case, the agent acted on behalf of the producer in Italy, and he did so without assuming an economic risk, which was borne by the principal and not by its agent. Regarding the second condition, the fact that the agent worked for two different undertakings is insufficient to demonstrate the agent's commercial independence, because he was following strict instructions from the principals and bore no financial risks resulting from the contracts. However, the agent could, at the same time, be regarded as constituting a single economic unit with one of his principals, but a separate economic unit to the other member of the cartel. After all, the agent was only seemingly autonomous and he did not undertake economic risk and activities similar to those of an independent service provider. Liability for its action was attributed to the undertaking in question on the basis of the single economic entity doctrine.

9 It stems directly from para. 39 of judgment of 16.11.2011, T-78/06 Álvarez, ECLI:EU:T:2011:673 and para. 22-23 of judgment of 22.05.2014, C-36/12 P Alvarez, ECLI:EU:C:2014:349.

10 Judgment of 15.07.2015, T-418/10 Voestalpine, ECLI:EU:T:2015:516.

11 Ibid. para. 20.

12 Ibid. para. 139.

13 Ibid. para. 163. 
There are also situations when liability for a violation of Article 101 TFEU is attributed to an economic successor of the infringing entity. ${ }^{14}$ The principle of economic continuity provides that an undertaking that takes over the infringing entity after the period of the infringement may also be held liable if the infringing entity during the period of the infringement either ceased to exist or is part of the same group of companies. If that entity is transferred to an independent undertaking, there is no economic continuity (Atlee, 2016). However, this concept will not be further discussed in this paper as it mainly concerns the economic continuity principle and does not include actions of independent service providers. Still, it should be mentioned as it is another broadly understood form of liability for third party actions.

The concepts discussed in this paragraph referred to situations where an employee, a subsidiary and a contractor's autonomy was seeming. Therefore, liability for such actions was attributed to the undertaking which exercised decisive influence over them. The Court considered that they formed a single entity for the purpose of incurring liability. Consequently, if an undertaking commits an infringement, all of the legal persons that constitute the relevant single entity are regarded as jointly and severally liable for the infringement regardless of the fact whether the parent company participated in the infringement passively or actively (indirectly or directly).

\section{Genuinely independent third party}

For the purpose of the analysis, several landmark cases and competition law concepts were chosen which show different perspectives on the liability for third party actions. The key question that this part of the article aims to answer is when is a third party considered to be genuinely independent.

As shown by previous paragraphs, in certain situations two or more undertakings may be treated as one. Therefore, having a separate legal personality does not suffice to consider another entity as independent. The Court repeatedly held that the "concept of an undertaking (...) covers entity engaged in an economic activity, regardless of the legal status of the entity or the way in which it is financed. That concept must be understood as covering an economic unit, even if, from a legal perspective, that unit is made up of a number of natural or legal persons. When such an economic entity infringes the competition rules, it is for that entity, according to the principle

14 Particularly interesting and providing insight into the concept of economic continuity is judgment of 14.07.2016, Case T-146/09 RENV Parker Hannifin Manufacturing Srl, ECLI:EU:T:2016:411. 
of personal responsibility, to answer for that infringement' ${ }^{15}$ Generally service providers are considered independent entities. ${ }^{16}$ Therefore, they are not part of the service recipient's organizational structure. It is crucial to determine whether a service provider de facto operates independently of its recipient. If independence is only seeming, that is, the service provider is legally a separate entity but actually performs his given activities under the control and strict supervision of the recipient, it might be considered to be part of the same economic unit as the parent company and the subsidiary. Accordingly, they may form a single undertaking for the purposes of Article 101 TFEU. ${ }^{17}$ There cannot be any links between the undertaking in question and the service provider that would lead to the conclusion that they form a single economic entity.

What other factors characterize a truly independent contractor? According to settled case law 18 it follows that the decisive factor for the purposes of determining whether a [contractor] (...) is an independent economic operator is to be found in the agreement concluded with the principal and, in particular, in the clauses of that agreement, implied or express, relating to the assumption of the financial and commercial risks linked to sales of goods to third parties (...) the question of risk must be analyzed on a case-by-case basis, taking account of the real economic situation rather than the legal classification of the contractual relationship in national law'. A contractor has to be a separate entity which bears commercial risk in its own name. For that reason, agency contracts are excluded, ${ }^{19}$ unless an agent carries any risk resulting from his agreement.

15 Para. 33 Total $S A$.

16 Para. 25 VM Remonts.

17 Para. 27 judgment of 16.06.2016, Case C-155/1 P Evonik Degussa, ECLI:EU:C:2016:446; para. 45-47 judgment of 18.01.2017, Case C-623/15 P Toshiba, ECLI:EU:C:2017:21.

18 Para. 46 of judgment of 14.12.2006, Case C-217/05 Confederación Española de Empresarios de Estaciones de Servicio v Compañía Española de Petróleos SA, ECLI:EU:C:2006:784. The requirement of bearing relevant economic risk is also confirmed by para. 139 Voestalpine.

19 According to the Guidelines on Vertical Restraints 2010/C 130/01 'the agreement will be qualified as an agency agreement if the agent does not bear any, or bears only insignificant, risks in relation to the contracts concluded and/or negotiated on behalf of the principal, in relation to market-specific investments for that field of activity, and in relation to other activities required by the principal to be undertaken on the same product market (...) If contract-specific risks are incurred by the agent, it will be enough to conclude that the agent is an independent distributor (...) Where the agent bears one or more of the relevant risks, the agreement between agent and principal does not constitute an agency agreement for the purpose of applying Article 101(1). In that situation, the agent will be treated as an independent undertaking'. Therefore, only if an agent assumes any risk resulting from his agreement is he considered an independent service provider. 
An independent contractor means that the contractor is accountable for its own unlawful conduct. As a rule, acts of rogue contractors cannot automatically be attributed to its recipients. However, if certain conditions are met, the undertaking in question is liable for third party actions.

\section{Test for the attribution of anti-competitive conduct of a service provider}

In this part, the paper focuses on liability for actions of a genuinely independent contractor which bears economic risk and is not controlled by the principal. It does not need approval for its actions, as it is operating within obligations imposed on it by an agreement. It needs to be highlighted that the contractor cannot be considered part of the undertaking in question; hence the concept of a single economic entity does not apply. The CJEU formulated a test in its recent case law for the attribution to the undertaking in question of anti-competitive conduct of an independent contractor.

The $A C$-Treuhand case discusses the liability of a cartel facilitator operating on a different market than the cartel members. Eturas ${ }^{20}$ is a case dealing with an antitrust violation that results from the conduct of an online platform. The judgment is followed by VM Remonts which further developed the reasoning and presumptions of liability for third party actions.

The first case referred to the consultancy firm AC Treuhand, which was organizing meetings for a number of cartelists. It played an active role in those meetings by resolving potential disputes between cartel members, as well as collecting and sharing confidential market data. The Court found that AC-Treuhand violated Article 101 TFEU by facilitating and coordinating a cartel among producers - the conduct of the consultancy firm had direct effect on the formation and functioning of the cartel. The Court said that the entity was aware of the anti-competitive object of the collaboration between the parties and contributed to that goal. ${ }^{21}$ Another important issue that was introduced by the judgment is that an undertaking and a service provider do not have to operate on the same market, that is, on the market affected by the infringement of competition law. ${ }^{22}$ The Court relied strongly in this judgment on the effet utile argument, ${ }^{23}$ which makes the interpretation wide and vague. For that reason, the judgment received some critical comments - sound and

\footnotetext{
20 Judgment of 21.01.2016, Case C-74/14 Eturas, ECLI:EU:C:2016:42.

21 Para. 37-39 AC-Treuhand.

22 Ibid. para. 27, 33-36.

23 Ibid, para. 36.
} 
reasonable justification was sacrificed on the altar of full effectiveness of Article 101 TFEU (Busher, Herz, and Vedder, 2015; Lamadrid and Villiers, 2015).

The factual background of the Eturas case is as follows: the online platform Eturas and 30 Lithuanian travel agencies were fined for participating in a concerted practice of coordinating discounts applicable to bookings made via the online system E-TURAS. A new, smaller online discount rate was communicated through personal electronic accounts, given to each travel agency that had access to the booking system. After sending the message, Eturas automatically implemented the discount cap. The main concern in the proceedings was whether sending a message containing a discounts cap could 'constitute sufficient evidence to confirm or to raise a presumption that the economic operators participating in the E-TURAS booking system knew or ought to have known about that restriction, even though some of them claim not to have had any knowledge of the restriction'. ${ }^{24}$

The CJEU stated that if travel agencies were aware of the content of the message, this would constitute the key element of the anti-competitive practice. Subsequently, it would give rise to a presumption that they participated in that practice by tacitly assenting to the new discount cap. ${ }^{25}$ Hence, the awareness of the infringement is a prerequisite of its existence, unless undertakings take steps to distance themselves from the concerted practice. Accordingly, the CJEU introduced the presumption of knowledge about the infringement. Sending a message alone is not enough to conclude that its addressees were aware of the content of that message. Knowledge must stem from other objective and consistent indicia. ${ }^{26}$

VM Remonts is the landmark case which further develops the liability regime for third party actions. It introduced another rebuttable presumption of liability for an anti-competitive conduct of an independent service provider. The judgment addressed the issue of liability of an undertaking ${ }^{27}$ for bidrigging arrangements set up and run by a consultancy firm, which was beyond that undertaking's control. The service provider colluded with two other

24 Para. 24. Eturas.

25 Ibid. para. 44. Also para. $31 A C$-Treuhand which states that 'passive modes of participation in the infringement, such as the presence of an undertaking in meetings at which anticompetitive agreements were concluded, without that undertaking clearly opposing them, are indicative of collusion capable of rendering the undertaking liable under Article [101 TFEU], since a party which tacitly approves of an unlawful initiative, without publicly distancing itself from its content or reporting it to the administrative authorities, encourages the continuation of the infringement and compromises its discovery'.

26 Para. 39 and 40 Eturas.

27 The undertaking in question, Partkias kompanija, hired law firm to prepare a tender offer. The latter entity subcontracted the task to MMD lietas, a consultancy firm. 
tenderers in a bid for a public contract. The Latvian competition authority in its decision imposed a fine on all three tenderers. ${ }^{28}$ The judgment of the Regional Administrative Court of Latvia annulled the decision in so far as it made a finding of infringement against the undertaking which hired the consultancy firm; still, it upheld the decision with regard to the other two tenderers. ${ }^{29}$

In paragraph 33, the CJEU referred to conditions which determine the liability of an undertaking for the acts of an independent contractor. These include the following:

- 'the service provider was in fact acting under the direction or control of the undertaking concerned, or

- that undertaking was aware of the anti-competitive objectives pursued by its competitors and the service provider and intended to contribute to them by its own conduct, or

- that undertaking could reasonably have foreseen the anti-competitive acts of its competitors and the service provider and was prepared to accept the risk which they entailed.'

The CJEU stated that an undertaking is liable if any of the aforementioned conditions are met.

The first condition raises no doubts, as it has already been explained and refers to issues analyzed in this paper. If the existence of organizational, economic and legal links between a parent company and its subsidiary or an undertaking and a service provider results in the provision of direction or control by the undertaking in question, then, there is no doubt in such circumstances that the undertaking can be held liable for the unlawful conduct of the service provider.

However, the second and third conditions have been criticized (Talbot, 2016, p. 234-235; Thomas, De Stefano and Jubrail, 2016; Knapp, 2016, p. 101-102) for their 'extending' approach to liability and for creating an almost automatic presumption which may be troublesome to rebut.

With regard to the second condition, the CJEU stressed that an undertaking can be held responsible for participating in concerted practices and agreements, if it was aware of the anti-competitive goals pursued by its competitors and the service provider, and intended to contribute to the unlawful practices. Both conditions are met if the undertaking intends to disclose confidential

${ }^{28}$ Interestingly, the NCA did not consider the liability of the consultancy firm that organized and oversaw the bid-rigging.

29 The case was appealed to the Supreme Court of Latvia which asked the Court of Justice for a preliminary ruling. The judgment of the Supreme Court of Latvia was issued on 31.10.2016 and it dismissed the proceedings, therefore the judgment of the Regional Administrative Court of Latvia is final. 
business information to its competitors via the service provider or gives explicit or tacit approval to do so. ${ }^{30}$ The CJEU clarified it further indicating that this condition will not be met if the service provider voluntarily and without the knowledge of the undertaking in question used confidential information to prepare competitive offers.

The third condition blurred the limits of liability as it refers to a situation where an undertaking has no knowledge of the anti-competitive intentions of the service provider, but could reasonably foresee that there would be a breach of competition law. The competent authority carries out an $e x$ post assessment of that undertaking's behavior. It seems that the aim of the assessment is to include situations when an undertaking engages contractors to avoid direct participation in any form of prohibited practices. The introduction of such a presumption imposes an obligation which is very difficult to fulfill by undertakings. It implies that an undertaking should closely monitor its contractors. In practice, this is a burdensome task because companies usually lack the knowledge and human resources necessary to supervise all the activities of their contractors. The silver lining here might be the fact that the burden of proof lies with the competition authority, which must prove in an indisputable manner that the undertaking knew or at least could find out that the actions of its service provider were meant to restrict competition. If an undertaking had to show evidence to rebut this presumption, this could turn, in practice, into 'mission impossible'. The case VM Remonts proposes a more undertaking-friendly approach, than the conclusion reached by the Advocate General in his opinion. ${ }^{31}$ However, it still carries many challenges for undertakings that outsource most of their activities.

Although the conditions of the test are not novel, as they were already introduced in older judgments, ${ }^{32}$ the test has not referred to liability for third party actions. Recent case law contributes to the interpretation of Article 101 TFEU and attempts to provide guidance both to authorities, on how to apply relevant competition law provisions, and to undertakings, on how to escape liability.

30 Para. 30 VM Remonts.

31 Opinion of Advocate General Wathelet delivered on 03.12.2015 in Case C-542/17 VM Remonts, ECLI:EU:C:2015:797. In his opinion, AG Wathelet proposed a reversed burden of proof, that it, the undertaking would have to provide evidence sufficient to rebut all of the presumptions indicating that the company colluded with/or through a service provider.

32 Para. 86-86 judgment of 08.07.1999, Case C-49/92 P Anic Partecipazioni, ECLI:EU:C:1999:356. 


\section{Grounds for exemption from liability for actions of a genuinely independent contractor}

The implications of the discussed cases are particularly important for undertakings which engage many contractors in their daily operations. It is not rare for competitors to share the same service providers, such as sellers, intermediaries and internet platforms. An undertaking will have to show due diligence and monitor closely the activities of its service providers, to minimize the risk of liability for their anti-competitive conduct and the possibility of potential claims for damages due to competition law infringements.

It is also worth noting that in VM Remonts, the realization was irrelevant for the attribution of liability that it was not the undertaking in question that hired the service provider. The law firm which was the intermediary and engaged the service provider was completely omitted. This means that the undertaking may be responsible for violations committed by a subcontractor. This can cause major problems for an undertaking, which usually has no information or resources necessary to closely supervise all of the outsourced activities and service providers, if it uses services of many intermediaries. Moreover, usually a subcontractor is accountable to the entity with which he concludes an agreement for specific works (Knapp, 2017, p. 102). Interestingly, in AC-Treuhand and Eturas, the cartel facilitator was fined for its antitrust conduct; by contrast, the subject of a consultancy firm providing services was not brought up. in VM Remonts Neither the Latvian NCA nor the CJEU discussed the issue of liability of the service provider which organized and supervised the cartel.

What must an undertaking do to exempt itself from liability? In light of relevant case law, if an undertaking wants to escape liability it should clearly distance itself from any unlawful conduct of a rogue contractor in a way that leaves no doubt that it was not a part of the cartel (Thomas, De Stefano and Jubrail, 2016). The CJEU provided in Eturas an exemplary list of means for undertakings to distance themselves from an infringement. This can take the form of a public announcement, information to other parties to the anticompetitive conduct, notice to a competition authority or other means, ${ }^{33}$ since the list is non-exhaustive. The Eturas and $A C$-Treuhand cases confirm that a third party can facilitate unlawful cooperation. In Eturas, the cooperation took a form that prevented any direct contact between the travel agencies co-using the platforms (Lawrance and Lisner, 2017). Another judgment penalized the consultancy firm which set up and ran the cartel meetings. It shows that if an undertaking fails to clearly distance itself from an anti-

33 Para. 46-49 Eturas. 
competitive practice, it may be held liable for actions of independent service providers. However, it is still ambiguous what evidence and other objective and consistent indicia will be taken into consideration and how they will be assessed by national courts to justify the presumption of having knowledge of an infringement (Lawrance and Lisner, 2017).

A practical implication for undertaking is that closer scrutiny of the contractual relationships with third parties, entrusted with activities that may raise competition law concerns, is required. Moreover, agreements must be carefully drafted, including confidentiality clauses or provisions limiting the possibility of a service provider cooperating with the competitors of the undertaking in questions (through exclusivity clauses). Although, these clauses do not completely eliminate the risk, they reduce it significantly. It is advised to constantly and comprehensively monitor current external and internal activity. The adoption of an appropriate compliance policy, and implementing rules for early detection of potential infringements, might be particularly justified and desirable in this case.

\section{Issues left unresolved}

There are some matters that are still unresolved and raise concerns. First, how should the expression 'reasonably have foreseen' be determined? It is not sufficiently clear which circumstances count as 'foreseeable'. Same doubts apply to the presumption of knowledge established in Eturas and confirmed by VM Remonts. An undertaking can monitor closely its direct contractors, but checking subcontractors might be beyond its capabilities, because the contractor will not usually disclose such data due to trade secrets or market competition. The question arises to what an extent can an undertaking be required to review its contractors? This seems to be stretching the limits of liability, but, at the same time, it does not provide for a sufficient level of clarity as to how it should be interpreted. Though there are no references to $A C$-Treuhand in $V M$ Remonts, the former judgment contributes to the interpretation of this condition by providing guidance on how to understand 'foreseeability' should be understood. The notion may depend on various factors, including 'content of the text in issue, the field it covers and the number and status of those to whom it is addressed'. ${ }^{34}$ Moreover, the result is still foreseeable, even if an undertaking must get legal advice to consider the full implications of its conduct. The interpretation provided by the Court raises many doubts and

34 Para. 42 AC-Treuhand. 
questions (cf. Busher, Herz and Vedder, H.,2015; Canu, 2015). A company's basic task is to conduct its business and provide services, not to dedicate most of its resources to a detailed verification of all its contractors. Overturning the presumption might cause many difficulties for companies.

Another question is what standard of proof is required to determine whether an undertaking is aware of a possible violation of Article 101 TFEU. There are certain requirements that competent authorities must meet. Principles governing the assessment of evidence and standard of proof can be found in national laws. Hence, the presumptions for liability originate in EU law, but handling evidence is governed by domestic rules of the Member States (Rusu, 2016, p. 2). In practice, this means that the outcome of a case greatly depends on the applicable legislation of a particular Member State, therefore different regimes translates into different outcome. It is the task of national courts to decide whether an undertaking fulfilled the conditions set out by the CJEU. In order to do so, a national court uses domestic rules on the assessment of evidence and standard of proof, and takes into account all the circumstances of the case. The court must then assess if the circumstances of the case (such as the dispatch of a message or possibility to reasonably foresee the anti-competitive acts of competitors and independent service provider) may constitute sufficient evidence.

The next issue refers to limits of liability. The gravity of the infringement is assessed on the basis of the unlawful conduct; as well as whether the undertaking in question participated in all aspects of an anti-competitive practice, or whether it only played a minor role therein. However, what if an undertaking's liability arises directly from its service provider's conduct - is the undertaking in question liable only within the limits of the infringement committed by its service provider? Should the corresponding reasoning from the single economic entity doctrine be applied whereby a parent company's liability depends exclusively on the facts constituting the infringement committed by its subsidiary and to which its liability is closely linked.

\section{Conclusion}

It is beyond doubt that an undertaking may be liable for infringements committed by its service providers. The liability of an undertaking cannot be ruled out even in the case of a genuinely independent contractor, which should be solely accountable for its own actions. As demonstrated by the aforementioned case law, to escape liability, an undertaking must prove it was not aware that an infringement existed or that a service provider was involved 
in anti-competitive practices. If the undertaking in question had no knowledge of the infringement, it still has to satisfy the 'foreseeability' condition, that is, show it did everything to identify the full implications of its actions and the actions of its service provider; and make sure none of them raised competition law concerns.

An undertaking is liable when a third party provides services only seemingly as an independent contractor and is, in fact, under the control of the undertaking in question or is related to it via organizational, economic and legal links. In this case, the single economic unit doctrine will apply and the aforementioned grounds for defense will, most probably, not be applicable.

There is a visible shift towards extending the interpretation of Article 101 TFEU; such course of action involves the risk of stretching this legal concept by using an interpretation that is overly broad. The judgments are part of the CJEU's case law on the scope of the subjective elements of liability for the involvement in a cartel established or facilitated by a service provider. Undertakings have to keep in mind that conduct of their subsidiaries and service providers may expose them to liability for fines and potential damages claims. Therefore, they not only have to keep an eye on the behavior of employees and entities associated with them on the basis of a single economic entity, but also on independent contractors and subcontractors as well as consider also the IT systems which they co-share with their competitors. The case by case approach will probably shift slightly, and subsequent judgments will work out the full implications and more detailed interpretation of the test.

\section{Literature}

Atlee, L.C. (2016). Third Time's a Charm: Parker-Hannifin and the Principles of Economic Continuity and Personal Liability. Retrieved from: https://www.lexology.com/library/ detail.aspx?g=531e8c77-5000-4103-9840-666d17b35686 (10.04.2018).

Busher, R., Herz, M. and Vedder, H. (2015). The Shortest Competition Judgment Ever: Ac-Treuhand II. Retrieved from: https://europeanlawblog.eu/2015/11/09/the-shortestcompetition-judgment-ever-ac-treuhand-ii/ (10.06.2018).

Canu, V. (2015). EU's highest court confirms liability of cartel facilitators. Retrieved from: http://competitionlawblog.kluwercompetitionlaw.com/2015/10/29/eus-highest-courtconfirms-liability-of-cartel-facilitators/ (10.06.2018).

Knapp, M. (2017). Odpowiedzialność przedsiębiorcy za udział w zmowie przetargowej będącej efektem zachowania jego usługodawcy. Glosa 2, 97-103.

Lamadrid, A. and Villiers, S. (2015). ECJ Judgment in AC-Treuhand (C-194/14 P) - On the scope of Art. 101 (1) TFEU. Retrieved from: https:/chillingcompetition.com/2015/10/26/ ecj-judgment-in-ac-treuhand-c-19414-p-on-the-scope-of-art-101-1-tfeu/ (10.06.2018). 
Lawrance, S. and Linsner, M. (2017). Eturas - Any conclusions on platform collusion..? Retrieved from: http://competitionlawblog.kluwercompetitionlaw.com/2017/01/19/ eturas-conclusions-platform-collusion/ (10.04.2018).

Moisejevas, R. and Urbonas, D. (2017). Problems Related to Determining of a Single Economic Entity under Competition Law. Yearbook of Antitrust and Regulatory Studies, 10(16), 107-125.Rusu, C. S. (2016). Eturas: Of Concerted Practices, Tacit Approval, and the Presumption of Innocence. Journal of European Competition Law \& Practice 7(6), 396-398.

Semeniuk, P. (2015). Koncepcja jednego organizmu gospodarczego. Warszawa, Wydawnictwo Naukowe Wydziału Zarządzania Uniwersytetu Warszawskiego.

Talbot, C. (2016). The ECJ's decision in VM Remonts and the extension of liability for the anticompetitive conduct of service providers under article 101(1) TFEU. Commercial Law Practitioner, 23(9), 233-235.

Thomas, C., De Stefano G. and Jubrail, D. (2016). Liability for anti-competitive behaviour by your employees and outside contractors: when you are off the hook and when you are not. Retrieved from: http://competitionlawblog.kluwercompetitionlaw.com/2016/08/04/ liability-anti-competitive-behaviour-employees-outside-contractors-off-hooknot/?print $=$ print $(10.04 .2018)$.

Vedder, H. (2014) The Kone Case And The Lifts Cartel - An Upward Effect On Prices And Effectiveness? Retrieved from: https://europeanlawblog.eu/2014/06/19/the-kone-caseand-the-lifts-cartel-an-upward-effect-on-prices-and-effectiveness/ (10.04.2018). 